\title{
Microclimate and soil moisture in a silvopastoral system in southeastern Brazil
}

\author{
José Ricardo Macedo Pezzopane ( ${ }^{\text {* }}$ ); Cristiam Bosi $\left({ }^{2}\right)$; Maria Luiza Franceschi Nicodemo (1); \\ Patrícia Menezes Santos ( $\left.{ }^{1}\right)$; Pedro Gomes da Cruz ( $\left.{ }^{3}\right)$; Renan Suaiden Parmejiani ( ${ }^{2}$ )
}

\author{
(') Embrapa Pecuária Sudeste, Caixa Postal 339, 13563-776 São Carlos (SP), Brasil. \\ (2) Universidade de São Paulo, Escola Superior de Agricultura “Luiz de Queiroz”, Programa de Pós-Graduação em Engenharia de \\ Sistemas Agrícolas, Avenida Pádua Dias, 11, 13418-900 Piracicaba (SP), Brasil. \\ (3) Embrapa Rondônia, Caixa Postal 127, 76815-800 Porto Velho (RO), Brasil. \\ $\left(^{*}\right)$ Corresponding author: jose.pezzopane@embrapa.br
}

Received: Sept. 25, 2014; Accepted: Dec. 13, 2014

\begin{abstract}
In this study, the microclimate changes in silvopastoral systems are quantified at different time and spatial scales and compared with single-pasture systems. The study was conducted in a silvopastoral system in São Carlos, Brazil (22 $01^{\prime}$ South and 4753' West). The silvopastoral system consisted of grass pastures [Urochloa (sin. Brachiaria) decumbens cv. Basilik] lined with strips of native trees spaced at $17 \mathrm{~m}$. Continuous microclimate measurements (air temperature, relative humidity, wind speed, and incident photosynthetically active radiation) were carried out from September 2010 to September 2012 at two positions of the silvopastoral system ( 2.0 and $8.5 \mathrm{~m}$ from the rows of trees) and at a pasture under full sunlight, located in an adjacent area. The soil moisture was monitored weekly from 24 March 2010 to 1 April 2012 at distances of 0.0, 2.0, 4.75, and 8.5 m from the rows of trees. The rows of native trees reduced wind speeds ( $46 \%$ reduction) and changed the photosynthetically active radiation incidence pattern on the pasture (up to $40 \%$ reduction of incidence at the point nearest to the trees). The combined action of these factors promoted thermal and air humidity changes on the pasture at the different points measured. With respect to soil moisture, there was greater soil moisture removal at the sampling points near the rows of native trees under the silvopastoral system, mainly due to enhanced exploration by tree roots at greater depths in dry spells or early dry periods, when compared with the midpoints between the rows.
\end{abstract}

Key words: solar radiation, air temperature, cattle, water balance, Urochloa decumbens.

\section{INTRODUCTION}

The association of trees with pastures, known as silvopastoral systems, is a form of intensification of livestock production. This practice is associated with increased land use efficiency (Dube et al., 2002), income diversification of livestock farms by generating additional products, as well as environmental benefits, and can also help to reduce problems caused by deforestation in agricultural frontier areas or help to recover degraded pastures (Dias, 2011). Forest species may also help control erosion and improve animal welfare and carbon fixation (Montagnini \& Nair, 2004).

In silvopastoral systems, when the systems are properly dimensioned, the trees and the pasture can successfully interact in order to optimize both productions. Besides the selection and use of shade-tolerant forage species, the level of competition in the silvopastoral system can be manipulated by the choice of tree species, tree density and arrangement of trees in relation to the sun and land relief, as well as by the use of silvicultural techniques for managing tree canopies and thinning (Pollock et al., 2009; Rozados-Lorenzo et al., 2007).

According to Young (1991) the main interactions of silvopastoral systems with the environment refer to the microclimate (solar radiation, air humidity, temperature, and wind) and the soil (soil moisture, erosion, and fertility) components. The trees, assisting to stabilize the microclimate, protect animals from extreme heat or cold by providing thermal comfort, with positive effects on the productivity of the herd (Baliscei et al., 2013; Souza et al., 2010).

Conducting systematic measures of the system components in terms of changes in soil fertility, microclimate, and availability of resources (water, nutrients, and light) can provide vital information to support management strategies to maximize the benefits of these interactions (Righi \& Bernardes, 2007).

The aim of this study was to evaluate the microclimate conditions and soil moisture storage in a silvopastoral 
system consisting of Urochloa (sin. Brachiaria) decumbens cv. Basilik pasture forested with native tree species in São Carlos, State of Sao Paulo, Brazil. The hypothesis tested in this study is that the trees present in the silvopastoral system promote changes in the microclimate and soil water content and these changes vary depending on the system development.

\section{MATERIAL AND METHOD}

The study was conducted in a silvopastoral system in São Carlos, Brazil (latitude 22 $01^{\prime}$ South and longitude $47^{\circ} 53^{\prime}$ West). The region's climate is classified as Cwa (Köppen), with two distinct seasons: dry from April to September and wet from October to March. The average annual temperature is $21.5^{\circ} \mathrm{C}$ and the annual relative humidity is $75.6 \%$. The region's land relief is smooth and wavy, with 3-5\% slopes, and an average altitude of $850 \mathrm{~m}$.

The experimental area was formed by Urochloa (sin. Brachiaria) decumbens cv. Basilik pasture in Oxisol (Soil Survey Staff, 1999). In approximately eight hectares, the trees were planted in December 2007 in the pasture areas in strips spaced at $17 \mathrm{~m}$, protected by an electric fence $1 \mathrm{~m}$ from the marginal line of trees, representing 15-m-wide pasture areas. The strips consisting of three rows of trees were spaced at $2.5 \mathrm{~m} \mathrm{x} 2.5 \mathrm{~m}$, resulting in about 545 trees $\mathrm{ha}^{-1}$. The forest species tested and planted on the midline were Anadenanthera colubrine, Peltophorum dubium, Zeyheria tuberculosa, Cariniana estrellensis, and Piptadenia gonoacantha. To ensure that these species grew straight boles with a minimum of lower branches, the tree species
Guazuma ulmifolia and Croton floribundus were planted in an alternating sequence in the two outer lines of each tree strip. In approximately $10 \%$ of the individuals of the outer line species (Guazuma ulmifolia and Croton florisbundum) the growth measures, performed in November 2010, 2011, and 2012, quantified that on average the tree heights were 4.6, 5.9, and $7.1 \mathrm{~m}$, respectively.

The pasture was used for grazing of beef cattle, in a rotational stocking method, with 35 days of rest and seven of grazing. The trial was conducted in a randomized block (padocks) design with four treatments (distance from the tree rows): Point 1 , located at the tree rows; Point 2 , pasture area next to the tree rows $\left(2\right.$ meters $\left.-\mathrm{SP}_{2 \mathrm{~m}}\right)$; Point 3 , pasture area in an intermediate position ( 4.75 meters $\left.-\mathrm{SP}_{4.75 \mathrm{~m}}\right)$; and Point 4, midpoint between two tree rows (8.5 meters distant $\left.-\mathrm{SP}_{8.5 \mathrm{~m}}\right)$. A diagram showing the location of collection points of the environment variables in the experiment is illustrated to help understand the methodology and the results (Figure 1). The sketch shows the tree rows with timber species in the midline $(\mathrm{M})$ and in the outer lines $(\mathrm{C})$.

Microclimatic measurements were performed on a representative location of the silvopastoral system in two distances of the tree rows (Point 2 and Point 4, Figure 1). For comparison microclimatic measurements were also carried out in a pasture under full sunlight in an area adjacent to the silvopastoral system.

The microclimatic measurements consisted of collecting the following data: air temperature and relative humidity (Campbell Scientific HMP 50), with sensors installed in multi-plate shelters, wind speed (Gill 2-D Sonic Wind Sensor) and photosynthetically active radiation (PAR) (Apogee SQ-311 Line Quantum Sensor), performed

\begin{tabular}{|c|c|c|c|c|c|c|c|c|c|c|c|c|c|c|c|c|}
\hline & C & & C & C & & C & C & C & C & C & c & & C & C & C & \\
\hline \multirow{8}{*}{$2.5 \mathrm{~m}$} & & $M$ & M & & $M$ & M & M & $M$ & $M$ & $N$ & & $M$ & M & M & & M \\
\hline & C & & $C$ & C & & $c$ & C & Point $^{\text {Point }}$ & ${ }^{7} c^{\text {(Trees }}$ & 5) $\mathrm{C}$ & c & & C & C & c & \\
\hline & & & & & & & & Point & $2(2 \mathrm{~m})$ & & & & & & & \\
\hline & & & & & & & & Point & $3(4.75$ & & & & & & & \\
\hline & & $17 \mathrm{~m}$ & & & & & & Point & $4(8.5 \mathrm{~m}$ & & & & & & & \\
\hline & C & & C & C & & C & C & C & C & C & ( & E & C & C & C & \\
\hline & & $M$ & M & & $M$ & M & M & M & M & $\mathrm{N}$ & & $M$ & $M$ & M & & M \\
\hline & C & & C & C & & c & C & C & C & C & ( & $E$ & C & C & c & \\
\hline
\end{tabular}

Figure 1. Representative sketch of the experimental area demonstrating the collection points of the silvopastoral system. M: midline species; C: Marginal species. 
continuously on the pasture canopy (approximately $70 \mathrm{~cm}$ high), between September 2010 and September 2012. The sensors were connected to an automated data acquisition system (Campbell Scientific CR1000), scheduled for readings every 10 seconds. The incidence of PAR on a pasture under full sunlight and PAR transmission in the silvopastoral system (average hourly) were assessed for each month of the experimental period and the results interpolated using inverse distance weighted (IDW) method.

Soil moisture was monitored weekly from 0 to $1 \mathrm{~m}$ in depth (every $0.1 \mathrm{~m}$ ), using a capacitance probe (Sentek Pty Ltd. model Diviner 2000, Stepney South Australia), from 24 Mar. 2010 to 1 Apr. 2012 at distances of 0.0, 2.0, 4.75, and $8.5 \mathrm{~m}$ (Points 1 to 4, Figure 1), in four replicates on one side of the shade of the tree species. Climatic water balance (Thornthwaite \& Mather, 1955) was estimated during the experimental period.

The MIXED SAS procedure (Statistical Analysis System, version 9.2) was used for the statistical analyses. The LSMEANS fixed effects were used to calculate the means of the models. For the microclimate variables, the fixed effects of the model were distance from the tree rows and season of the year. The collection days were considered as the model's random effect. For the soil moisture, the fixed effects of the model were distance from the tree row, soil depths, and their interactions, and the Akaike information criterion (AIC) was used to choose the variance and covariance matrix that best fit the model. Significant fixed effects were compared by Tukey test at 5\% significance. When appropriate, regression analyses were performed on the soil profile data for soil moisture.

\section{RESULTS AND DISCUSSION}

The trees introduced into the pastures prompted environmental changes in the pasture (Table 1). The analyses of the entire measurement period showed differences between the silvopastoral system and the pasture area under full sunlight for all weather parameters measured $(\mathrm{p}<0.01)$.
There were also differences between the measurement points inside the silvopastoral system for most of the weather parameters measured, mainly for the incidence of solar radiation (photosynthetically active radiation - PAR) and winds (average speed and maximum gust).

The trees attenuated the incidence of PAR; average daily values throughout the measuring periods decreased by around $40 \%$ at the point nearest to the trees $\left(\mathrm{SP}_{2 \mathrm{~m}}\right)$ and by $9 \%$ at the midpoint between two rows of trees $\left(\mathrm{SP}_{8.5 \mathrm{~m}}\right)$ (Table 1). The sunlight transmitted through the tree canopies in silvopastoral systems has significant impact on forage production (Silva-Pando et al., 2002). In excessive shade conditions, the sunlight filtered through the tree canopies is enriched in near-infrared relative to red, thus the red/far-red ratio is correlated with plant response to shading or a perceived threat of shading. This response in forages includes elongation of internodes and reduced tillering (Feldhake, 2001). The sunlight transmission values obtained in this study suggest that no significant damage occurred to the forage production, as the reduction of $35 \%$ of transmission $\left(\mathrm{SP}_{2 \mathrm{~m}}\right)$ is still within a tolerable range for the species (Paciullo et al., 2007; 2011).

Observing the average hourly PAR incidence and the transmission of PAR in two measurement points of the silvopastoral system (Figure 2), a change is observed during the measurement periods, as well as during the different measurement times, due to growth of the trees and the rows' orientation. Transmissivity was lower in the second year than in the first year of measurements. At the measurement point closest to the row of trees $\left(\mathrm{SP}_{2 \mathrm{~m}}\right)$, the transmission values were lower in the afternoon from May to June, a fact that was more evident in the second year of measurements. As for the midpoint between the rows, the lowest transmissions occurred during the hours closer to sunrise or sunset, also with lower transmissions in the second year of measurements. Transmissivity throughout the year was also influenced by the apparent path of the sun, which varies throughout the year at the latitude where the experiment was conducted. Higher solar radiation transmissivity occurred during the spring/summer months, when the angle of sunlight incidence is smaller.

Table 1. Daily climatic element values collected in pastures under full sunlight (FS) and at two points of the silvopastoral system (SP ${ }_{2 \mathrm{~m}}$ and $\mathrm{SP}_{8.5 \mathrm{~m}}$ ) from September 2010 to September 2012, in São Carlos (SP), Brazil

\begin{tabular}{|c|c|c|c|}
\hline \multirow{2}{*}{ Climatic element } & \multicolumn{3}{|c|}{ Position } \\
\hline & FS & $\mathrm{SP}_{2 \mathrm{~m}}$ & $\mathrm{SP}_{8.5 \mathrm{~m}}$ \\
\hline Photosynthetically active radiation, $\mathrm{MJ} \mathrm{m}^{-2}$ day $^{-1}$ & $7.6 a$ & $4.6 \mathrm{c}$ & $7.0 \mathrm{~b}$ \\
\hline Maximum daily wind speed, $\mathrm{m} \mathrm{s}^{-1}$ & $6.7 \mathrm{a}$ & $4.6 \mathrm{c}$ & $4.8 \mathrm{~b}$ \\
\hline Minimum daily temperature, ${ }^{\circ} \mathrm{C}$ & $14.5 \mathrm{a}$ & $14.5 \mathrm{a}$ & $14.4 b$ \\
\hline Maximum daily temperature, ${ }^{\circ} \mathrm{C}$ & $28.3 b$ & $27.5 \mathrm{c}$ & $29.5 \mathrm{a}$ \\
\hline Medium temperature, ${ }^{\circ} \mathrm{C}$ & $20.3 \mathrm{a}$ & $20.1 \mathrm{~b}$ & $20.3 \mathrm{a}$ \\
\hline Medium relative humidity, \% & $73.8 \mathrm{~b}$ & $73.0 \mathrm{c}$ & $74.9 \mathrm{a}$ \\
\hline
\end{tabular}

* Means followed by the same letter in rows are not significantly different ( $\mathrm{p}<0.05$; Tukey's test). 

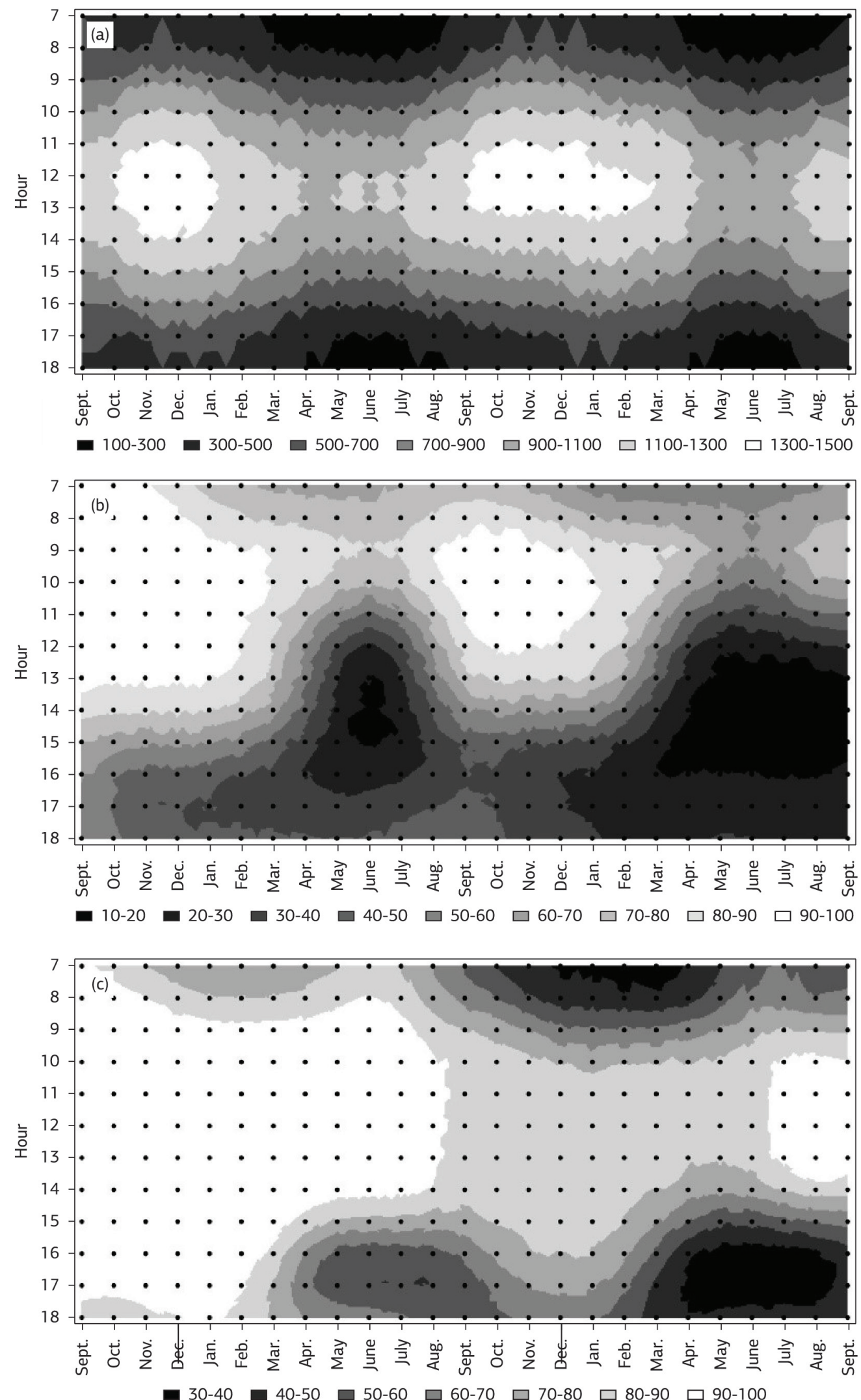

Figure 2. Hourly average values of photosynthetically active radiation $\left(\mu \mathrm{mol} \mathrm{m} \mathrm{mec}^{-1}\right)$ in pastures under full sunlight (a), average hourly PAR transmission in the silvopastoral system 2.5 meters from the rows of trees (b) and hourly average PAR transmission in the silvopastoral system 8.5 meters from the rows of trees (c) from September 2010 to September 2012 in São Carlos (SP), Brazil. 
There was an interaction between season of the year and distance from the tree rows, for all meteorological variables measured (Table 2). For PAR incidence in the spring, there was no difference between the pasture under full sunlight and $\mathrm{SP}_{8.5 \mathrm{~m}}$, and the incidences in the autumn/winter months were lower than in the spring/summer months.

For both measurement points in the silvopastoral system, the incidence of winds was $47 \%$ lower than that observed in the single-pasture system (Table 1). This observation demonstrates the importance of plant arrangement in tree rows acting as windbreaks. Baliscei et al. (2013), Souza et al. (2010) found that, in terms of reduced incidence of winds, microclimatic changes in the silvopastoral systems promoted better animal comfort.

Wind speed (average) was higher during winter/spring compared with summer/fall; a similar trend was observed for maximum gust. For all seasons the single-pasture system values were higher than those for the sampling points of the silvopastoral system (Table 2). This reduction in the maximum gust may be important to prevent mechanical damage to plants and animals to stress conditions. The combined change in the PAR incidence and wind in the silvopastoral system also promoted air temperature and relative humidity changes. The most evident differences were related to maximum temperature. Higher values were obtained in $\mathrm{SP}_{8.5 \mathrm{~m}}\left(29.5^{\circ} \mathrm{C}\right)$ than in the pasture under full sunlight $\left(28.3^{\circ} \mathrm{C}\right)$ and the point close to the trees $\left(27.5^{\circ} \mathrm{C}\right)$. It should be highlighted that in $\mathrm{SP}_{8.5 \mathrm{~m}}$, in the afternoon, PAR transmissivity was always above $80 \%$ and close to $100 \%$ in most of the experiment (Figure 2). The maximum temperatures were recorded for $\mathrm{SP}_{4.75 \mathrm{~m}}$ which had the highest values at all times, showing spatial variability of this element within the silvopastoral system. For minimum and medium temperatures, although statistical differences were found between the points, the values are very close.

The closest point to the shade of the tree rows caused a reduction in maximum temperatures, especially in the afternoon, time of occurrence of maximum temperatures. Similar results were obtained in other silvopastoral systems using rows (Baliscei et al., 2013) or for other crops under systems arranged with tree rows (Pezzopane et al., 2010). The relative humidity values (directly related to temperature)

Table 2. Seasonal variation of climatic elements collected in pastures under full sunlight (FS) and at two points of the silvopastoral system $\left(\mathrm{SP}_{2 \mathrm{~m}}\right.$ and $\left.\mathrm{SP}_{8.5 \mathrm{~m}}\right)$ from September 2010 to September 2012 in Sáo Carlos (SP), Brazil

\begin{tabular}{|c|c|c|c|c|}
\hline \multirow{2}{*}{ Position } & \multicolumn{4}{|c|}{ Season } \\
\hline & Spring & Summer & Autumn & Winter \\
\hline \multicolumn{5}{|c|}{ Photosynthetically active radiation, $\mathrm{MJ} \mathrm{m}^{-2} \mathrm{dia}^{-1}$} \\
\hline FS & $8.8 \mathrm{Aa}$ & 8.2 Aa & $6.1 \mathrm{Ab}$ & $6.7 \mathrm{Ab}$ \\
\hline $\mathrm{SP}_{2 \mathrm{~m}}$ & $7.2 \mathrm{Ba}$ & $5.9 \mathrm{Cb}$ & $2.5 \mathrm{Cc}$ & $2.9 \mathrm{Cc}$ \\
\hline $\mathrm{SP}_{8.5 \mathrm{~m}}$ & $8.6 \mathrm{Aa}$ & $8.0 \mathrm{Ba}$ & $5.6 \mathrm{Bb}$ & $6.0 \mathrm{Bb}$ \\
\hline \multicolumn{5}{|c|}{ Wind speed, $\mathrm{m} \mathrm{s}^{-1}$} \\
\hline FS & $1.7 \mathrm{Aa}^{*}$ & $1.3 \mathrm{Ac}$ & $1.2 \mathrm{Ac}$ & $1.5 \mathrm{Ab}$ \\
\hline $\mathrm{SP}_{2 \mathrm{~m}}$ & $0.9 \mathrm{Ba}$ & $0.6 \mathrm{Bc}$ & $0.5 \mathrm{Bc}$ & $0.8 \mathrm{Bb}$ \\
\hline $\mathrm{SP}_{8.5 \mathrm{~m}}$ & $0.9 \mathrm{Ba}$ & $0.6 \mathrm{Bc}$ & $0.6 \mathrm{Bc}$ & $0.8 \mathrm{Bb}$ \\
\hline \multicolumn{5}{|c|}{ Maximum daily wind speed, $\mathrm{m} \mathrm{s}^{-1}$} \\
\hline FS & 7.5 Aa & $6.5 \mathrm{Ab}$ & $5.9 \mathrm{Ac}$ & $6.7 \mathrm{Ab}$ \\
\hline $\mathrm{SP}_{2 \mathrm{~m}}$ & $5.3 \mathrm{Ba}$ & $4.3 \mathrm{Bbc}$ & $4.0 \mathrm{Bc}$ & $4.6 \mathrm{Cb}$ \\
\hline $\mathrm{SP}_{8.5 \mathrm{~m}}$ & $5.4 \mathrm{Ba}$ & $4.6 \mathrm{Bbc}$ & $4.1 \mathrm{Bc}$ & $4.9 \mathrm{Bb}$ \\
\hline \multicolumn{5}{|c|}{ Minimum daily temperature, ${ }^{\circ} \mathrm{C}$} \\
\hline FS & 15. $5 \mathrm{Ab}$ & $17.7 \mathrm{Aa}$ & $13.7 \mathrm{Ac}$ & $11.2 \mathrm{Bd}$ \\
\hline $\mathrm{SP}_{2 \mathrm{~m}}$ & $15.3 \mathrm{Bb}$ & $17.7 \mathrm{ABa}$ & $13.7 \mathrm{Ac}$ & $11.2 \mathrm{Ad}$ \\
\hline $\mathrm{SP}_{8.5 \mathrm{~m}}$ & $15.3 \mathrm{Bb}$ & $17.6 \mathrm{Ba}$ & $13.5 \mathrm{Bc}$ & $11.1 \mathrm{Cd}$ \\
\hline \multicolumn{5}{|c|}{ Maximum daily temperature, ${ }^{\circ} \mathrm{C}$} \\
\hline FS & $29.5 \mathrm{Ba}$ & $29.8 \mathrm{Ba}$ & $26.7 \mathrm{Bb}$ & $27.2 \mathrm{Bb}$ \\
\hline $\mathrm{SP}_{2 \mathrm{~m}}$ & $29.3 \mathrm{Ca}$ & $29.1 \mathrm{Ca}$ & $25.3 \mathrm{Cb}$ & $26.4 \mathrm{Cb}$ \\
\hline $\mathrm{SP}_{8.5 \mathrm{~m}}$ & $30.6 \mathrm{Aa}$ & $31.2 \mathrm{Aa}$ & $27.8 \mathrm{Ab}$ & $28.4 \mathrm{Ab}$ \\
\hline \multicolumn{5}{|c|}{ Medium temperature, ${ }^{\circ} \mathrm{C}$} \\
\hline FS & $21.5 \mathrm{Ab}$ & $22.4 \mathrm{Ba}$ & $19.0 \mathrm{Ac}$ & 18.1 $\mathrm{Ad}$ \\
\hline $\mathrm{SP}_{2 \mathrm{~m}}$ & $21.4 \mathrm{Bb}$ & $22.2 \mathrm{Ca}$ & $18.6 \mathrm{Cc}$ & $18.0 \mathrm{Bc}$ \\
\hline $\mathrm{SP}_{8.5 \mathrm{~m}}$ & $21.6 \mathrm{Ab}$ & $22.6 \mathrm{Aa}$ & $18.9 \mathrm{Bc}$ & $18.1 \mathrm{Ac}$ \\
\hline \multicolumn{5}{|c|}{ Medium relative humidity, $\%$} \\
\hline FS & $71.1 \mathrm{Bb}$ & $79.4 \mathrm{Ba}$ & $78.1 \mathrm{Ba}$ & $66.6 \mathrm{Bc}$ \\
\hline $\mathrm{SP}_{2 \mathrm{~m}}$ & $70.0 \mathrm{Cb}$ & $78.2 \mathrm{Ca}$ & $78.1 \mathrm{Ba}$ & $65.5 \mathrm{Cc}$ \\
\hline $\mathrm{SP}_{8.5 \mathrm{~m}}$ & $71.7 \mathrm{Ab}$ & $80.3 \mathrm{Aa}$ & $80.2 \mathrm{Aa}$ & $67.5 \mathrm{Ac}$ \\
\hline
\end{tabular}

* Means followed by the same capital letter in rows or small letter within a column are not significantly different $(\mathrm{p}<0.05$; Tukey's test). 
showed that, with lower air removal at the midpoint between rows, there were higher values (maximum and average) found at this sample point.

In general, the differences in temperature and relative humidity between the seasons of the experiment followed the prevailing climatic conditions, with higher temperatures during spring/summer and lower during autumn/winter, with an inverse behavior for relative humidity (Table 2).

During the experimental period a soil moisture monitoring showed good consistency with the climatic water balance, based on data from the meteorological station located next to the experiment (Figure 3). In late winter 2010, after the occurrence of a prolonged drought period, the water storage levels in the soil reached minimum values (close to $160 \mathrm{~mm}$ ). In periods with excess water (summers 2010 and
2011) the storage values reached maximum values (close to $250 \mathrm{~mm}$ ). The fluctuation of values of moisture storage in the soil was similar among the sampling sites.

Considering the entire soil profile analyzed (0 to $100 \mathrm{~cm})$, the periods of soil moisture removal were after the rainy months, characterized by dry spells (February 2011 and 2012) or the beginning of the dry season (May 2010 and 2011). In such cases, at the points close to the row of trees (points 1 and 2 , distances of 0 and 2 meters) there was significantly higher moisture removal (Figure 4) than at more midpoints in the rows, mainly in May 2010 and February 2011. The trees under this system are found in semi-deciduous forest, partially losing leaves under water stress. The highest soil desiccation during dry spells and late rainy seasons indicates greater evapotranspiration, concomitantly accompanied
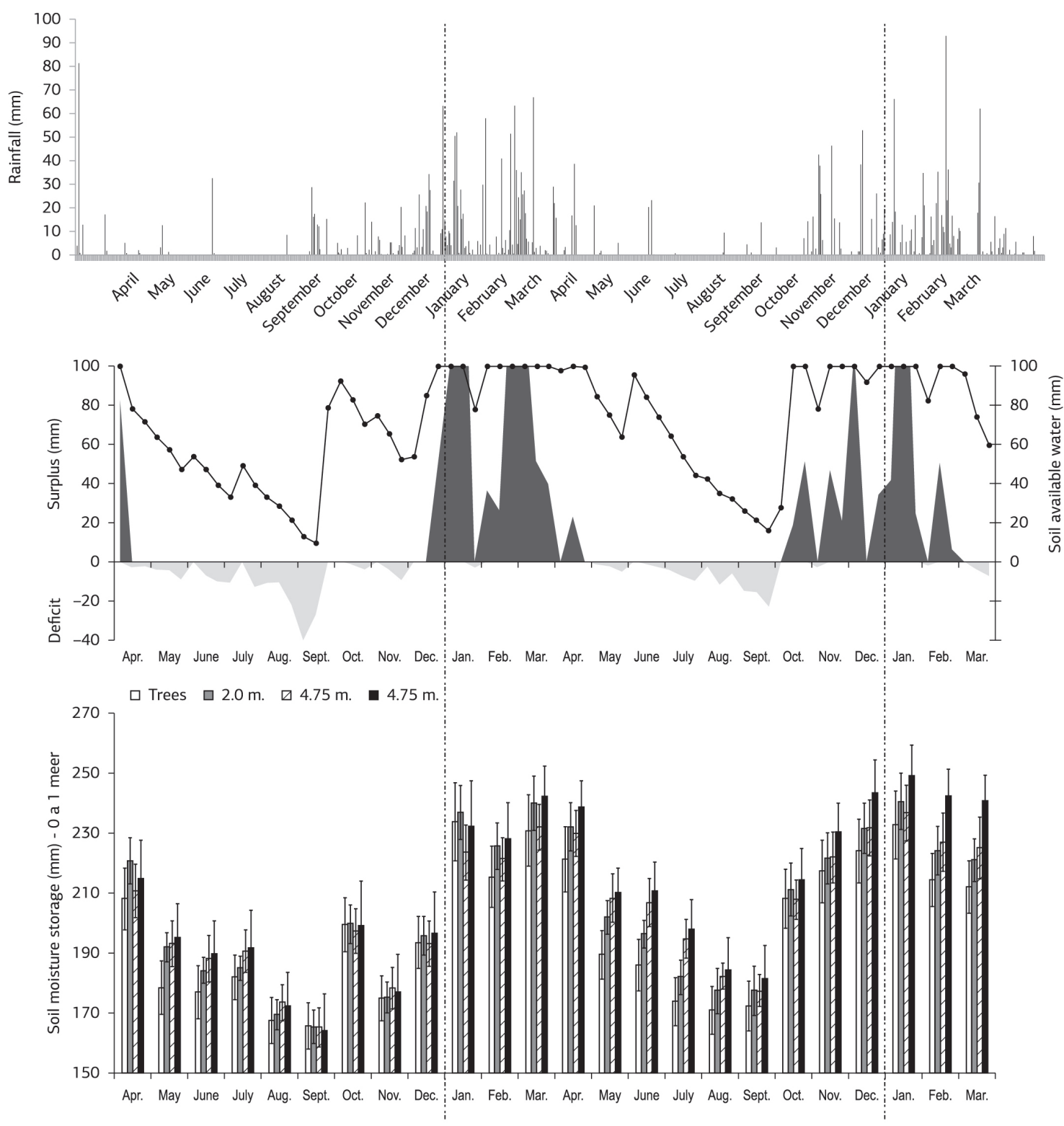

Figure 3. Rain, climatic water balance (decendial base) and soil moisture storage (monthly average) at four points of a silvopastoral system (row of trees and at 2.0, 4.75 and $8.5 \mathrm{~m}$ from the row of trees) from April 2010 to March 2012 in São Carlos (SP), Brazil. 

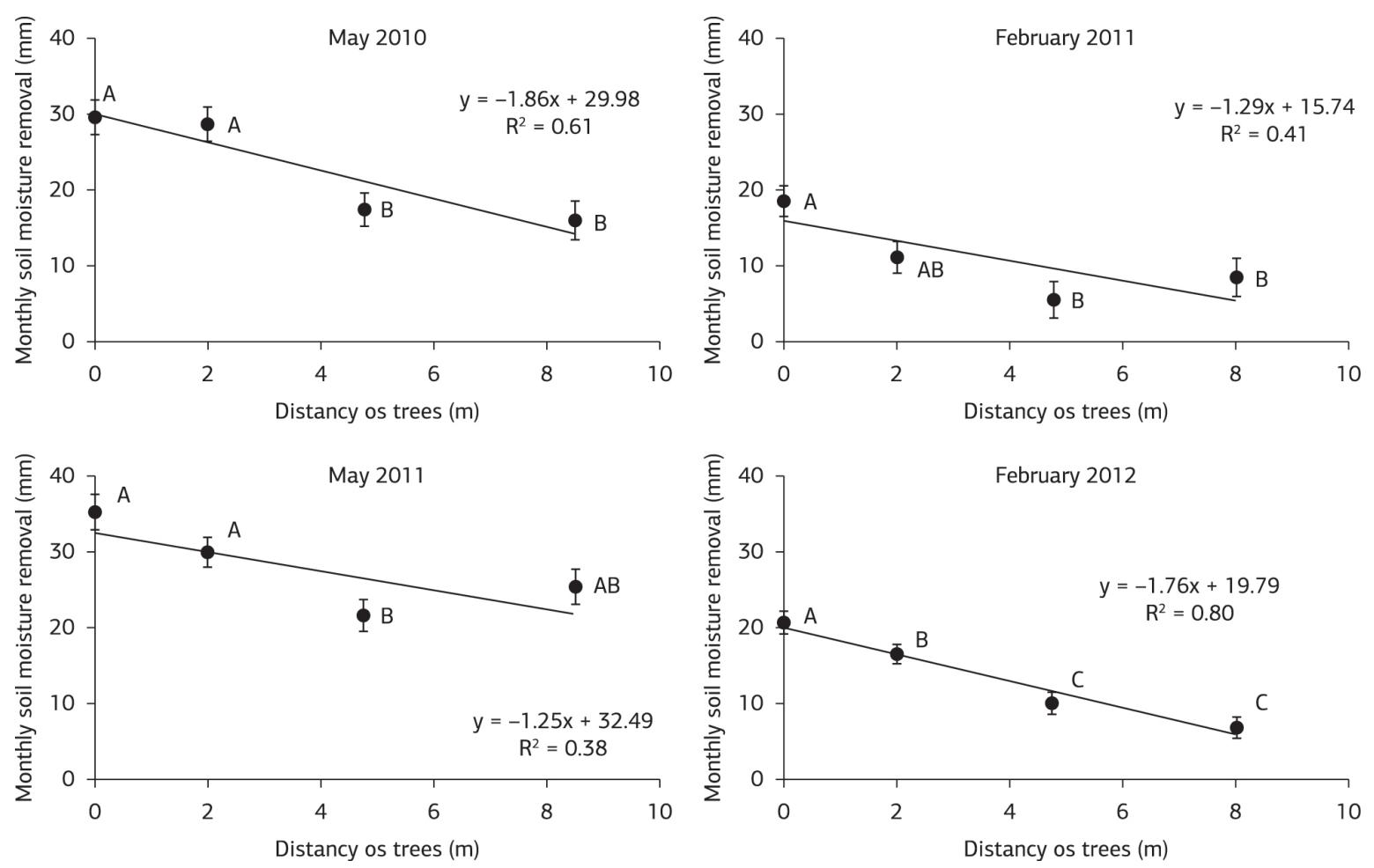

Figure 4. Linear regressions of the monthly soil moisture removal (0-100 cm deep) depending on the distance of trees in a silvopastoral system for four different dates, in São Carlos (SP), Brazil.

by greater moisture absorption from the soil. The data in figure 4 indicate that competition for water between trees and pasture is less critical during the dry season, when water demand by trees decreases because of a smaller leaf area.

Water soil dynamics in integrated systems depends on the region's rainfall and configuration (arrangement) of its components, which may present higher levels of soil moisture characteristics (Paciullo et al., 2008; Soares et al., 2009) or faster soil desiccation near the trees (Wilson, 1998), as obtained in this work.

The soil moisture profiles of 03 Sep., 24 Sep., and 01 Oct. 2010 characterize late dry season and beginning of the rainy season (Figure 5 - left). Between 03 and 24 Sep. there was virtually no soil moisture removal in any position relative to the row of trees, given that after the great drought period no moisture was available for the plants in the soil (Figure 3). In late September, the occurrence of $90 \mathrm{~mm}$ of rain provided water replenishment of about $60 \mathrm{~cm}$ deep. There were no differences between positions for a statistical comparison between distances, except for the measurement point at the rows of trees where the soil moisture content was significantly higher, up to $70 \mathrm{~cm}$ in the profile $01 \mathrm{Oct}$. 2010 against the profile 24 Spt. 2010, while at the other measurement points the differences were approximately $60 \mathrm{~cm}$ deep.
In another soil moisture replenishment period, between 03 and 17 Oct. 2011 (Figure 5, right), the occurrence of $156 \mathrm{~mm}$ of rain was enough to provide statistical differences in soil moisture between the profiles for all measurement points (distance from the tree rows) between all depths $(0-100 \mathrm{~cm})$. The results for the replenishment periods do not allow one to verify soil structure differences due to the presence of trees that could enable greater rainwater retention in the profile.

Soil moisture consumption differences between the tree row distances were verified in the examples of characteristic profiles of soil moisture removal periods (Figure 6). From 04 Jan. to 01 Feb. 2011 (Figure 6, left) the moisture content of the profiles was different at $60 \mathrm{~cm}$ deep in the tree rows, and up to $40 \mathrm{~cm}$ in $\mathrm{SP}_{2 \mathrm{~m}}$ and up to $20 \mathrm{~cm}$ in $\mathrm{SP}_{4.75 \mathrm{~m}}$ and $\mathrm{SP}_{8.5 \mathrm{~m}}$. Between 23 Jan. and 09 Feb. 2012 (Figure 6, right) the moisture content of the profiles was different at $60 \mathrm{~cm}$ deep in the row of trees, and up to $50 \mathrm{~cm}$ in $\mathrm{SP}_{2 \mathrm{~m}}$ and $30 \mathrm{~cm}$ in $\mathrm{SP}_{4.75 \mathrm{~m}}$ and up to $20 \mathrm{~cm}$ in $\mathrm{SP}_{8.5 \mathrm{~m}}$. The soil moisture removal in both episodes indicates that at points near the tree rows there was greater activity of the root system (possibly the trees) at deeper levels. Gyenge et al. (2002) and Pollock et al. (2009) report that silvopastoral systems have greater potential to exploit water resources, particularly deep moisture capture by the trees. 

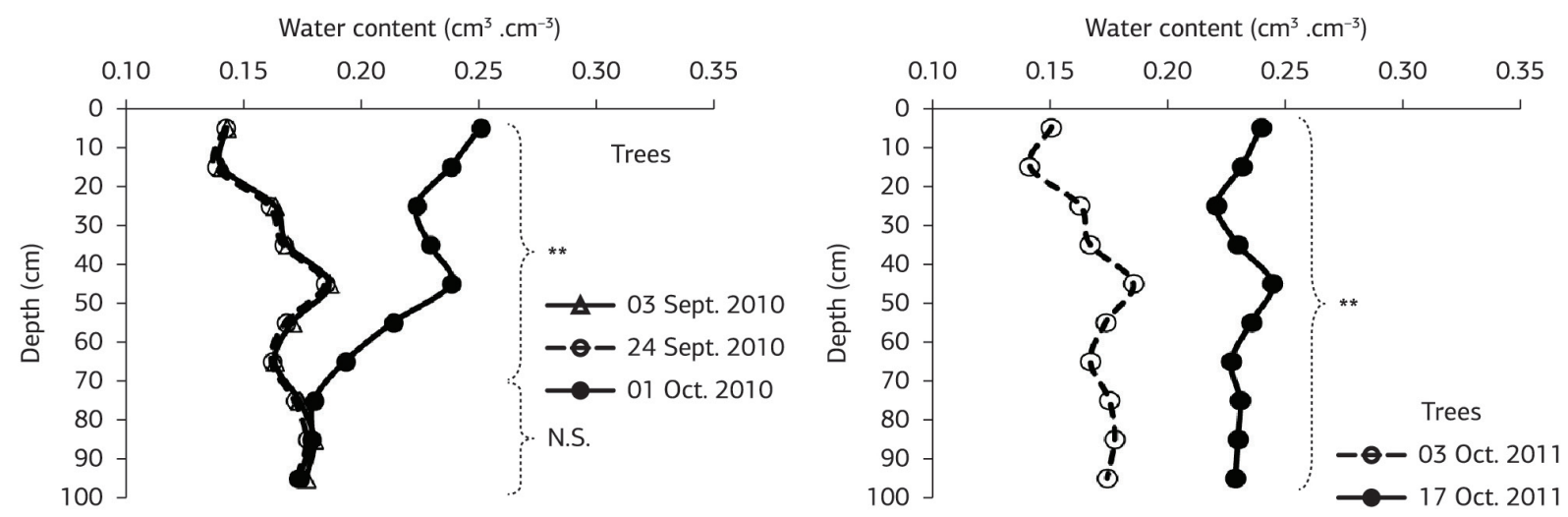

Water content $\left(\mathrm{cm}^{3} . \mathrm{cm}^{-3}\right)$
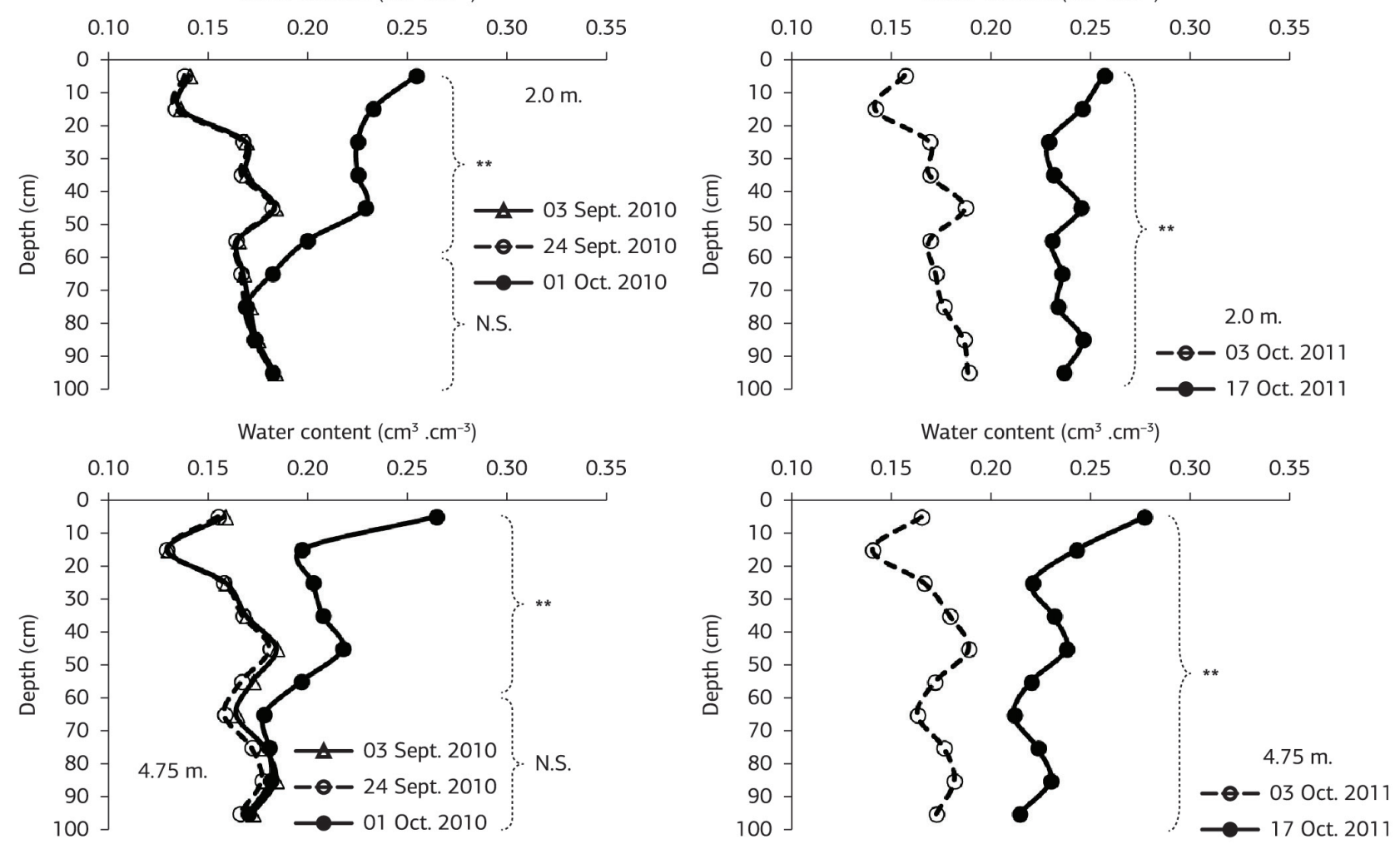

Water content $\left(\mathrm{cm}^{3} . \mathrm{cm}^{-3}\right)$
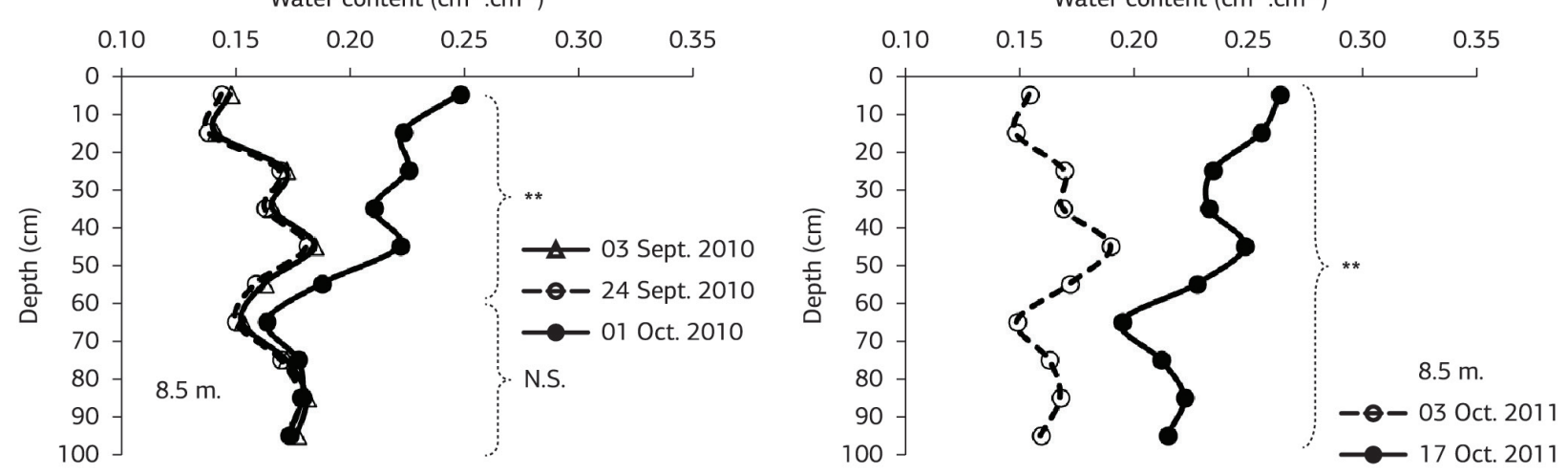

Figure 5. Water content variations $(0-100 \mathrm{~cm}$.) at four points in a silvopastoral system (row of trees and at 2.0, 4.75 and $8.5 \mathrm{~m}$. from the row of trees) in two soil moisture replenishment events (24 Sep. to 01 Oct. 2010 and 03 Oct. to 17 Oct. /2011) in Sáo Carlos (SP), Brazil. 
Water content $\left(\mathrm{cm}^{3} . \mathrm{cm}^{-3}\right)$

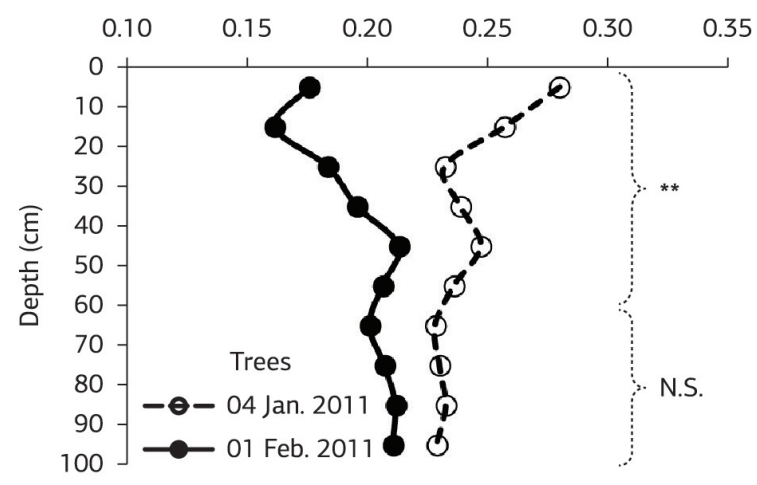

Water content $\left(\mathrm{cm}^{3} . \mathrm{cm}^{-3}\right)$

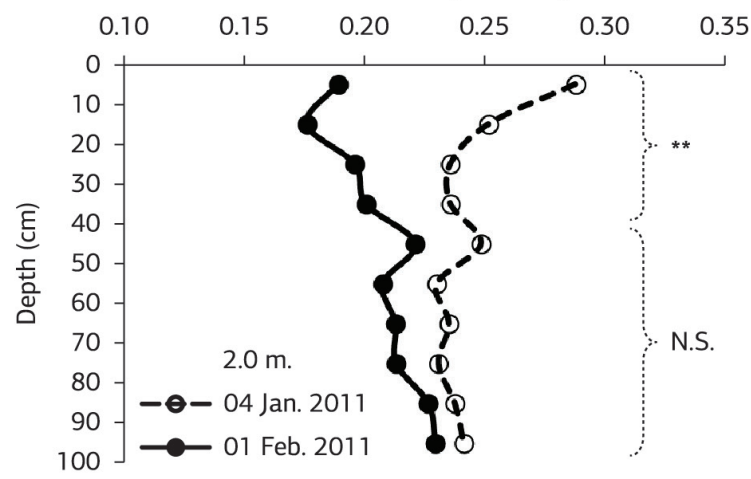

Water content $\left(\mathrm{cm}^{3} . \mathrm{cm}^{-3}\right)$

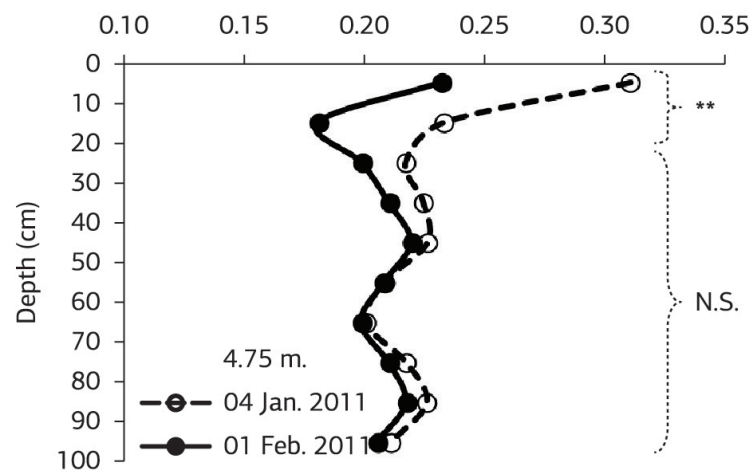

Water content $\left(\mathrm{cm}^{3} . \mathrm{cm}^{-3}\right)$

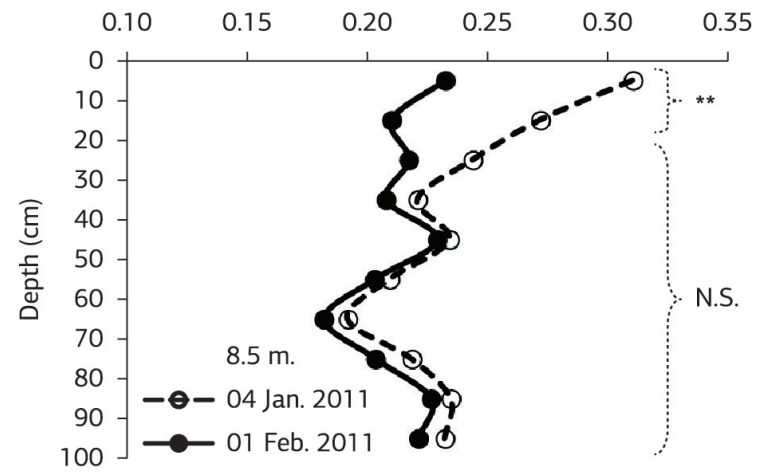

Water content $\left(\mathrm{cm}^{3} . \mathrm{cm}^{-3}\right)$

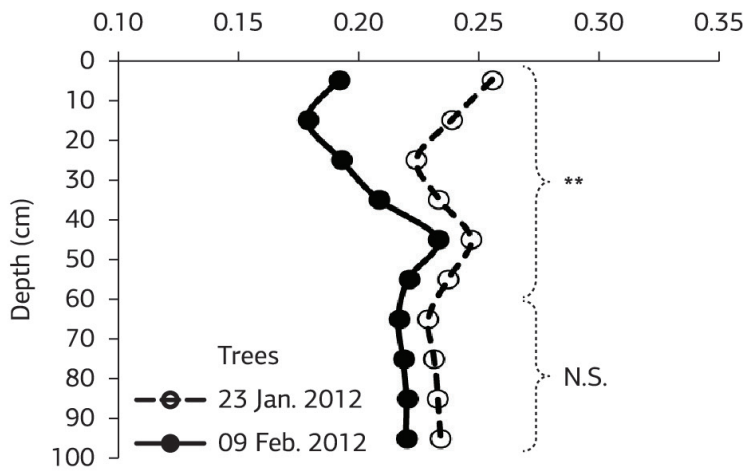

Water content $\left(\mathrm{cm}^{3} \cdot \mathrm{cm}^{-3}\right)$

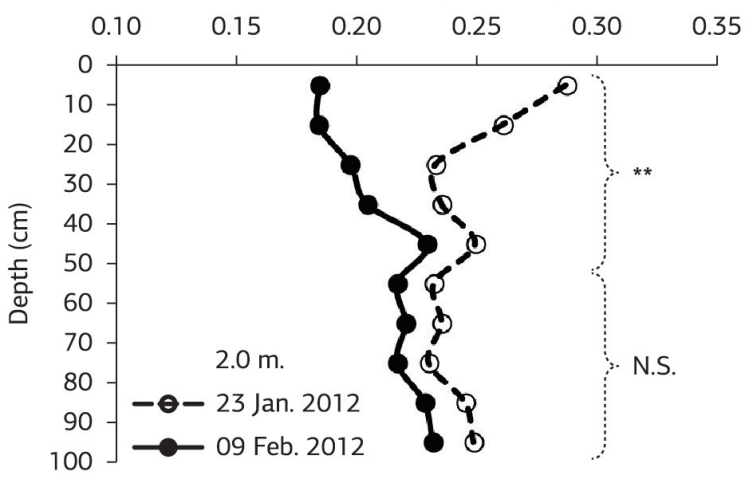

Water content $\left(\mathrm{cm}^{3} . \mathrm{cm}^{-3}\right)$

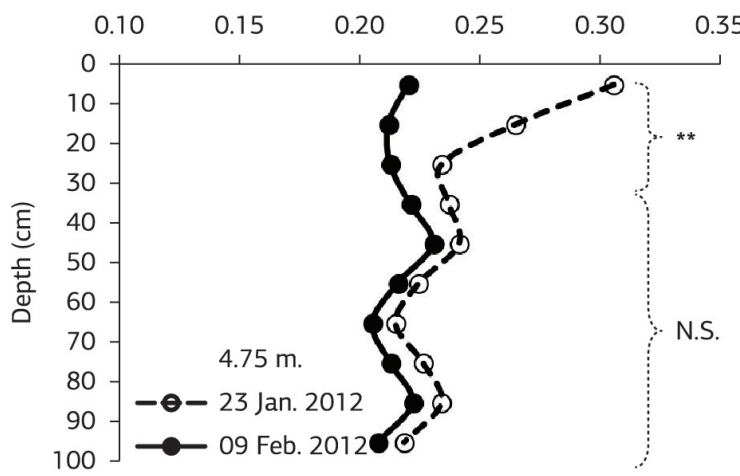

Water content $\left(\mathrm{cm}^{3} . \mathrm{cm}^{-3}\right)$

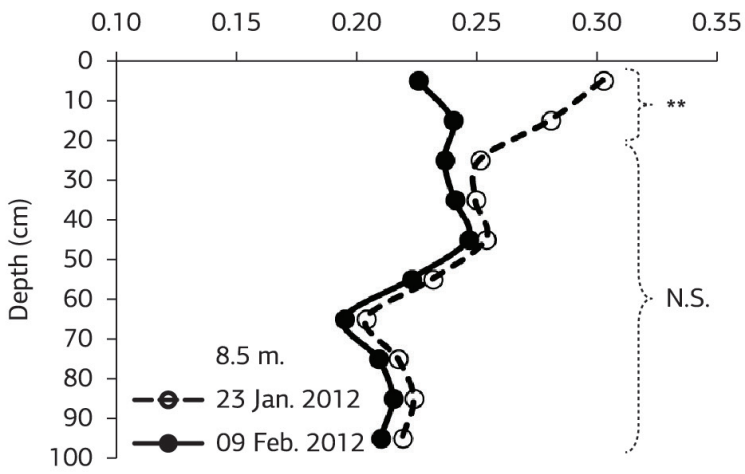

Figure 6. Soil moisture content variations $(0-100 \mathrm{~cm}$.) at four points in a silvopastoral system (row of trees and at 2.0, 4.75 and $8.5 \mathrm{~m}$ from the row of trees in two soil moisture removal events (04 Jan. to 01 Feb. 2011 and 23 Jan. to 09 Feb. 2012) in São Carlos (SP), Brazil. 


\section{CONCLUSION}

The presence of rows of native trees under the silvopastoral system decreases the occurrence of winds (47\% reduction) and alters patterns of incident PAR on the pasture areas (reduction of up to $40 \%$ ). Due to wind and solar radiation changes in the silvopastoral system there are thermal and relative air humidity changes, with a greater effect on the diurnal values and on the sampling point near the rows of trees. At the sampling points near the rows of native trees under the silvopastoral system there is greater soil moisture removal mainly due to greater exploration of tree roots at greater depths compared with the midpoints between rows.

\section{ACKNOWLEDGEMENTS}

To Conselho Nacional de Desenvolvimento Científico e Tecnológico, for financial support.

\section{REFERENCES}

Baliscei, M. A., Barbosa, O. R., Souza, W., Costa, M. A. T., Krutzmann, A., \& Queiroz, E. O. (2013). Microclimate without shade and silvopastoral system during summer and winter. Acta Scientiarum. Animal Sciences, 35, 49-56.

Dias, M. B., Fo. (2011). Os desafios da produção animal em pastagens na fronteira agrícola brasileira. Revista Brasileira de Zootecnia/Brazilian. Journal of Animal Science, 40, 243-252.

Dube, F., Couto, L., Silva, M. L., Leite, H. G., Garcia, R., \& Araújo, G. A. A. (2002). A simulation model for evaluating technical and economic aspects of an industrial eucalyptus-based agroforestry system in Minas Gerais, Brasil. Agroforestry Systems, 55, 73-80. http:// dx.doi.org/10.1023/A:1020240107370.

Feldhake, C. M. (2001). Microclimate of a natural pasture under planted Robinia Pseudoacacia in central Appalachia, West Virginia. Agroforestry Systems, 53, 297-303. http://dx.doi.org/10.1023/A:1013331628494.

Gyenge, J. E., Fernández, M. E., Dalla Salda, G., \& Schlichter, T. M. (2002). Silvopastoral systems in Northwestern Patagonia II: water balance and water potential in a stand of Pinus ponderosa and native grassland. Agroforestry Systems, 55, 47-55.

Montagnini, F., \& Nair, P. K. R. (2004). Carbon sequestration: underexploited environmental benefit of agroforestry systems. Agroforestry Systems, 61-62, 281-295. http://dx.doi.org/10.1023/ B:AGFO.0000029005.92691.79.

Paciullo, D. S. C., Campos, N. R., Gomide, C. A. M., Castro, C. R. T., Tavela, R. C., \& Rossiello, R. O. P. (2008). Crescimento de capim-braquiária influenciado pelo grau de sombreamento e pela estação do ano. Pesquisa Agropecuária Brasileira, 43, 917-923. http:// dx.doi.org/10.1590/S0100-204X2008000700017.

Paciullo, D. S. C., Carvalho, C. A. B., Aroeira, L. J. M., Morenz, M. F., Lopes, F. C. F., \& Rossiello, R. O. P. (2007). Morfofisiologia e valor nutritivo do capim-braquiária sob sombreamento natural e a sol pleno. Pesquisa Agropecuária Brasileira, 42, 573-579. http:// dx.doi.org/10.1590/S0100-204X2007000400016.

Paciullo, D. S. C., Fernandes, P. B., Gomide, C. A. M., Castro, C. R. T., Souza, F., So., \& Carvalho, C. A. B. (2011). The growth dynamics in Brachiaria species according to nitrogen dose and shade. Revista Brasileira de Zootecnia, 40, 270-276. http://dx.doi.org/10.1590/ S1516-35982011000200006.

Pezzopane, J. R. M., Marsetti, M. M. S., Souza, J. M., \& Pezzopane, J. E. M. (2010). Condiçóes microclimáticas em cultivo de café conilon a pleno sol e arborizado com nogueira macadâmia. Ciência Rural, 40, 1257-1263. http://dx.doi.org/10.1590/S0103-84782010005000098.

Pollock, K. M., Mead, D. J., \& McKenzie, B. A. (2009). Soil moisture and water use by pastures and silvopastures in a sub-humid temperate climate in New Zealand. Agroforestry Systems, 75, 223-238. http:// dx.doi.org/10.1007/s10457-008-9172-z.

Righi, C. A., \& Bernardes, M. S. (2007). Available radiant energy and beans phytomass accumulation in an agroforestry system with rubber trees. Revista Brasileira de Agrometeorologia, 15, 143-151.

Rozados-Lorenzo, M. J., González-Hernández, M. P., \& Silva-Pando, F. J. (2007). Pasture production under different tree species and densities in an Atlantic silvopastoral system. Agroforestry Systems, 70, 53-62. http://dx.doi.org/10.1007/s10457-007-9032-2.

Silva-Pando, F. J., González-Hernández, M. P., \& Rozados-Lorenzo, M. J. (2002). Pasture production in a silvopastoral system in relation with microclimate variables in the atlantic coast of Spain. Agroforestry Systems, 56, 203-211. http://dx.doi.org/10.1023/A:1021359817311.

Soares, A. B., Sartor, L. R., Adami, P. F., Varella, A. C., Fonseca, L., \& Mezzalira, J. C. (2009). Influência da luminosidade no comportamento de onze espécies forrageiras perenes de verão. Revista Brasileira de Zootecnia, 38, 443-451. http://dx.doi.org/10.1590/ S1516-35982009000300007.

Soil Survey Staff (1999). Soil taxonomy: a basic system of soil classification for making and interpreting soil surveys (2nd ed.). Washington: U.S. Government Printing Office.

Souza, W., Barbosa, O. R., Marques, J. A., Teixeira, M. A. T., Gasparino, E., \& Limberger, E. (2010). Microclimate in silvipastoral systems with eucalyptus in rank with different Heights. Revista Brasileira de Zootecnia, 39, 685-694. http://dx.doi.org/10.1590/ S1516-35982010000300030.

Thornthwaite, C. W., \& Mather, J. R. (1955). The water balance. New Jersey: Centerton.

Wilson, J. R. (1998). Influence of planting four tree species on the yield and soil water status of gree panic pasture in subhumid southeast Queensland. Tropical Grasslands, 32, 209-220.

Young, A. (1991). Agroforestry for soil conservation. Nairobi: ICRAF. 